\title{
Deficyt budżetowy i dług publiczny oraz kompetencje organów władzy do ich kształtowania - w świetle przepisów konstytucji i prawa Unii Europejskiej
}

\author{
State Authorities' Powers to Determine the Budget Deficit \\ and Public Debt in the Light of the Articles of the Constitution \\ and the Law of the European Union
}

\begin{abstract}
Streszczenie. Sprawy długu i deficytu regulowane są w konstytucjach (m.in. polskiej, niemieckiej, hiszpańskiej) i w prawie Unii Europejskiej. Regulacje konstytucyjne dotyczące długu i deficytu publicznego są normami skierowanymi głównie do rządów i parlamentów. Jednak mają one raczej charakter prewencyjny, sygnalizacyjny. Nie mogą same przez się zatrzymać poziomu zadłużania się państwa. Cele finansowe dotyczące długu i deficytu mogą być osiągnięte metodami niefinansowymi - odpowiednią polityką społeczną i gospodarczą, realizowaną przez władze cieszące się dużym autorytetem. Regulacje UE dotyczące długu i deficytu mogą być wprowadzane w życie tylko instrumentami prawa krajowego. Bardzo wątpliwy i podważający autorytet państwa jest zespół przepi-
\end{abstract}


sów unijnych ograniczających uprawnienia budżetowe państw członkowskich, w tym uprawnienia budżetowe rządów i parlamentów narodowych.

Słowa kluczowe: deficyt budżetowy; dług publiczny; konstytucja; prawo UE.

\begin{abstract}
The issues of public debt and budget deficit are regulated by constitutions (e.g. of Poland, Germany, Spain) as well as by the law of the European Union. The constitutional regulations concerning public debt and deficit are norms primarily directed at governments and parliaments. However, these regulations mainly have a preventive and auxiliary character and cannot by themselves stop the debt level of the state from increasing. Financial aims concerning debt and deficit can be achieved by non-financial methods, i.e. through the appropriate social and economic policies implemented by the authorities enjoying considerable social respect. The EU regulations regarding public debt and deficit can only be implemented with the instruments of the national law. The set of the EU regulations limiting the budgetary powers of member states, including the budgetary powers of governments and national parliaments, are questionable and undermine the authority of the state.
\end{abstract}

Keywords: budget deficit; public debt; the constitution; the law of the EU.

\title{
1. Przedstawienie problemu
}

Deficyt budżetowy, czyli sytuacja, gdy część rocznych wydatków państwa jest finansowana przy pomocy pożyczek ${ }^{1}$, oraz - będące konsekwencją deficytów - zadłużenie państwa (państwowy dług publiczny) są nie tylko instytucjami ekonomiczno-finansowymi, ale także instytucjami prawa, m.in. prawa konstytucyjnego i finansowego. Instytucje te mają określone ujęcie prawne. Jakie regulacje prawne określają kształt tych kategorii finansowych? Czy dług i deficyt mogą być - siłą przepisów prawnych ograniczane, modyfikowane, zmieniane? Jakie są lub mogą być konsekwencje uregulowań konstytucyjnych dotyczących długu i deficytu?

\footnotetext{
$1 \quad$ Według danych ministerstwa finansów dochody budżetu państwa na rok 2013 wyniosą 275 mld 729 mln zł, a wydatki 327 mld 294 mln zł. Deficyt budżetu państwa (nie całego sektora finansów publicznych) wynosi więc $51 \mathrm{mld} 565 \mathrm{mln}$ zł. Oznacza to, że wydatki budżetu państwa - finansowane deficytem - to ok. 16\% ogółu wydatków.
} 
Pytania te będą tu analizowane głównie w zakresie dotyczącym budżetu państwa ujętego w ustawie budżetowej. Będą one badane od strony wybranych regulacji konstytucyjnych (polskich, niemieckich, hiszpańskich), przepisów Traktatu o funkcjonowaniu Unii Europejskiej i innych przepisów UE.

\section{Dług publiczny i deficyt budżetowy w konstytucjach wybranych państw}

\section{Polska}

Konstytucja $\mathrm{RP}^{2}$ zagadnienia długu publicznego i deficytu budżetowego normuje głównie w art. 216 i art. 220. Z przepisów tych wynika, że emisja przez Skarb Państwa papierów wartościowych w celu finansowania deficytu, zaciąganie przez państwo pożyczek oraz udzielanie gwarancji i poręczeń finansowych przez państwo następują na zasadach i w trybie określonych w ustawie (art. 216 ust. 2 i 4). Ustawami dotyczącymi tych spraw są: przede wszystkim ustawa o finansach publicznych ${ }^{3}$, ustawa o poręczeniach i gwarancjach udzielanych przez Skarb Państwa oraz niektóre osoby prawne ${ }^{4}$, a w wymiarze wykonawczym i corocznym - ustawa budżetowa.

Inna zasada konstytucyjna stanowi, że nie wolno zaciągać pożyczek lub udzielać gwarancji i poręczeń finansowych, w następstwie których państwowy dług publiczny przekroczy 3/5 wartości rocznego produktu krajowego brutto.

Gdyby odpowiednie organy (Rada Ministrów, Minister Finansów, Prezes Narodowego Banku Polskiego) zaciągnęły zobowiązania finansowe przekraczające pułap określony w art. 216 ust. 5 (60\% wartości produktu krajowego brutto) to osoby pełniące funkcje tych organów popełni-

2 Konstytucja Rzeczypospolitej Polskiej z dnia 2 kwietnia 1997 r. (Dz.U. Nr 78, poz. 483 ze zm.).

3 Ustawa z dnia 27 sierpnia 2009 r. o finansach publicznych (tekst jedn. Dz.U. z 2013 r., poz. 885 ze zm.).

$4 \quad$ Ustawa z dnia 8 maja 1997 r. o poręczeniach i gwarancjach udzielanych przez Skarb Państwa oraz niektóre osoby prawne (tekst jedn. Dz.U. z 2012 r., poz. 657 ze zm.). 
łyby delikt konstytucyjny, a ponadto Trybunał Konstytucyjny powinien uchylić, jako niezgodny z Konstytucją, akt prawny, na podstawie którego zaciągnięto zobowiązania przekraczające ten pułap 5 .

Według art. 220 ust. 1 Konstytucji zwiększenie wydatków lub ograniczenie dochodów planowanych przez Radę Ministrów nie może powodować ustalenia przez Sejm większego deficytu budżetowego niż przewidziany w projekcie ustawy budżetowej. Sejm nie może ustalić wyższego poziomu deficytu budżetowego od tego, który zaproponowany został przez Radę Ministrów w przedłożonym Sejmowi projekcie ustawy budżetowej. Sejm uchwala ustawę budżetową - to jednak w istocie rząd decyduje o jej podstawowym elemencie, tj. o wysokości deficytu. Sejm nie może (w świetle Konstytucji) określić deficytu innego, niż ustalony przez rząd w projekcie ustawy budżetowej.

Rozwiązanie konstytucyjne dotyczące deficytu budżetowego, przewidziane jest także w art. 220 ust. 2 Konstytucji, który stanowi, że ustawa budżetowa nie może przewidywać pokrywania deficytu budżetowego przez zaciąganie zobowiązania w centralnym banku państwa. Narodowy Bank Polski nie jest zobowiązany udzielać pożyczek Skarbowi Państwa, skierowanych na finansowanie wydatków budżetowych, ani nie jest zobowiązany do kupowania obligacji skarbowych. Ustawa budżetowa (ani inna ustawa) nie może obligować NBP do stosowania wspomnianych operacji o charakterze pożyczkowym, służącym finansowaniu deficytu budżetu państwa. Przepis ten można łączyć z zasadą (art. 227 ust. 1 Konstytucji), że NBP przysługuje wyłączne prawo ustalania i realizowania polityki pieniężnej oraz że odpowiada on za wartość polskiego pieniądza.

W Drugiej Rzeczypospolitej uważano ${ }^{6}$, że pożyczki nie są dochodami budżetowymi, ale antycypacją przyszłych dochodów, i że pożyczki państwowe (o ile w ogóle je stosować) powinny być kierowane na cele twórcze, inwestycyjne. Dochody z pożyczek nie były ujmowane w budżecie, natomiast spłata pożyczek (kapitału i odsetek) następowała z kredy-

5 B. Banaszak, Konstytucja Rzeczypospolitej Polskiej. Komentarz, Warszawa 2012, s. 1047.

6 T. Grodyński, Zasady gospodarstwa budżetowego w Polsce na tle porównawczym, Kraków 1932, s. 49. 
tów (wydatków) budżetowych ${ }^{7}$. Wpływy z pożyczek i ich użycie (przeznaczenie) określano w odrębnych ustawach.

\section{Niemcy}

Konstytucja RFN znowelizowana w 2009 r. (BGBl. I 2009, s. 2248) zawiera rozbudowane regulacje dotyczące spraw długu i deficytu. Stanowi ona w art. 109, że związek i kraje związkowe wypełniają zobowiązania wynikające $\mathrm{z}$ traktatów unijnych dotyczące dyscypliny budżetowej i uwzględniają w swej gospodarce budżetowej wymagania ogólnej równowagi gospodarczej. Budżety tych władz powinny być równoważone w zasadzie bez udziału kredytów. Art. 115 konstytucji niemieckiej ustala, że zaciągnięcie przez władze federalne kredytu lub udzielenie poręczenia bądź gwarancji - które prowadzi do wydatków budżetowych w przyszłych okresach - wymaga upoważnienia ustawowego. Przepis ten wprowadza też zasadę, zgodnie z którą równowaga budżetowa jest zachowana, gdy wpływy budżetowe z tytułu kredytów przeznaczone na finansowanie deficytu budżetowego nie przekraczają 0,35\% nominalnego produktu krajowego brutto. Reguła 0,35\% PKB jako granica finansowania deficytu ma jednak (przewidziane w art. 115) wyjątki. Dotyczą one: odchyleń w przebiegu koniunktury gospodarczej, katastrof naturalnych oraz nadzwyczajnych sytuacji.

Przepisy niemieckiej ustawy zasadniczej (art. 115 ust. 1) stanowią, że zaciąganie kredytów w danej wysokości oraz udzielanie poręczeń lub gwarancji wymagają upoważnienia ustawowego. Upoważnienie to jest na ogół elementem ustawy budżetowej. Ustawa dająca to upoważnienie jest wyrazem kierowania przez parlament poczynaniami rządu w sprawach dotyczących długu publicznego. Służy temu, aby respektować uprawnienie budżetowe parlamentu. Ustawa budżetowa określająca upoważnienie do zaciągania kredytów na dany rok i w danej wysokości jest podstawą prawną do ich zaciągania, obowiązującą przez okres roku. Jest to upoważnienie dotyczące gromadzenia dochodów (zaciągania kredytów).

I. Weinfeld, Skarbowość polska, Z. 2 Budżet, kasowość, wydatki, dochody, długi, waluty, Warszawa 1933, s. 118. 
Wysokość kredytów, które można w danym roku zaciągnąć, określona w ustawie budżetowej - jest kwotą brutto. W granicach tej kwoty rząd (minister finansów) może zaciągać kredyty w danym roku ${ }^{8}$.

Poddaje się w wątpliwość, czy granica 0,35\% nominalnego produktu krajowego brutto (jako granica rocznego deficytu) wynika z określonych koncepcji merytorycznych, czy jest wynikiem politycznego pragmaty$\mathrm{zmu}^{9}$.

Wcześniejsza wersja art. 115 konstytucji RFN stanowiła, że wpływy z zaciągniętych kredytów rządowych nie powinny przekraczać kwoty przewidzianej w budżecie na cele inwestycyjne, a wyjątki od tej zasady dopuszczalne były w przypadku potrzeby zachowania ogólnej równowagi gospodarczej ${ }^{10}$. Przewidziane więc były dwie granice dotyczące zaciągania długu - finansowanie inwestycji państwowych i względy ogólnej równowagi gospodarczej.

Współcześnie w literaturze niemieckiej zauważa się, że sprawy ograniczenia i wysokości długu wynikają głównie z prawa Unii Europejskiej. W tekstach tych wskazuje się na różne poziomy norm prawnych dotyczących długu publicznego: przepisy UE (zwłaszcza art. 126 Traktatu), regulacje konstytucji, regulacje ustaw, przepisy rozporządzeń wykonawczych $^{11}$. Stawiane są pytania, czy te ograniczenia są realne.

\section{Hiszpania}

Konstytucja Hiszpanii z 27 grudnia 1978 r. $^{12}$ w art. 135 reguluje sprawy deficytu i długu publicznego i ich granic. Określa zasady stabilności budżetowej, przejmując do treści konstytucji (do art. 135) przepisy Unii Europejskiej zawarte w Traktacie o funkcjonowaniu Unii Europejskiej (art. 126 Traktatu). Art. 135 został zmieniony i rozbudowany (ustawą

\footnotetext{
8 M. Heintzen, [w:] I. Münch, P. Kunig (red.), Das Finanzwesen, Grundgesetz Kommentar, wyd. 6, Monachium 2012, s. 1317-1318.

Tamże, s. 1196.

10 Por. R.F. Heller, Haushaltsgrundsätze für Bund, Länder und Gemeinden, Heidelberg 2010, s. $471 \mathrm{i} \mathrm{n.}$

11 M. Heintzen, Das Finanzwesen, Grundgesetz Kommentar ..., s. 1200-1201.

12 Tekst w: W. Staśkiewicz (red.), Konstytucje państw Unii Europejskiej, Wydawnictwo Sejmowe, Warszawa 2011, s. 341 i n.
} 
z 27 września 2011 r. o zmianie artykułu 135 Konstytucji Hiszpanii) $)^{13}$. Zgodnie z nowym art. 135 ust. 1 wszystkie organy administracji publicznej dostosują swoją działalność do zasady stabilności budżetowej. Według ust. 2 tego artykułu państwo i wspólnoty autonomiczne nie mogą dopuścić do tego, by deficyt strukturalny przekroczył limit ustalony przez Unię Europejską dla jej państw członkowskich. Odpowiednia ustawa organiczna $^{14}$ ustalić ma maksymalny deficyt strukturalny dopuszczalny na poziomie budżetu państwa i budżetów wspólnot autonomicznych w odniesieniu do ich produktu krajowego brutto.

Konstytucja Hiszpanii stanowi (art. 135 ust. 3), że państwo i wspólnoty autonomiczne nie mogą emitować długu publicznego ani zaciągać kredytów bez ustawowego upoważnienia. Kredyty przeznaczone na spłatę odsetek i kapitału długu publicznego zawsze muszą być zapisane w budżetach jako część wydatków, a ich spłata ma charakter priorytetowy. Wysokość długu publicznego wszystkich organów administracji publicznej w stosunku do produktu krajowego brutto całego państwa nie może przekroczyć poziomu odniesienia ustalonego w Traktacie o funkcjonowaniu Unii Europejskiej.

Progi deficytu strukturalnego i wysokości długu publicznego mogą zostać przekroczone jedynie w przypadku katastrof naturalnych, recesji gospodarczej lub nagłych wyjątkowych sytuacji, które wymknęłyby się spod kontroli państwa i szkodziłyby w znaczącym stopniu sytuacji finansowej albo równowadze społeczno-gospodarczej państwa, według oceny absolutnej większości członków Kongresu Deputowanych (art. 135 ust. 4). Ustawa organiczna ma rozwinąć postanowienia art. 135, m.in. rozkład progów deficytu i długu pomiędzy poszczególne organy administracji publicznej, metodologię i procedury obliczania deficytu strukturalnego, odpowiedzialność każdego z organów administracji publicznej w przypadku nieosiągnięcia celów stabilizacji budżetowej. Postanowiono jedno-

\footnotetext{
Tamże, s. 372.

Ustawy organiczne to ustawy o szczególnym, większym znaczeniu. Dla uchwalenia, zmiany lub uchylenia ustaw organicznych jest wymagana absolutna większość członków Kongresu Deputowanych w głosowaniu końcowym nad całością projektu (por. art. 81 Konstytucji Hiszpanii).
} 
cześnie, że progi deficytu strukturalnego ustanowione w art. 135 Konstytucji wchodzą w życie w 2020 r.

Zauważyć należy, że przedstawione przepisy Konstytucji Hiszpanii wypełniają regulacje Unii Europejskiej, a także że są bardzo podobne do regulacji konstytucyjnych Niemiec, normujących sprawy deficytu i zadłużenia publicznego. Fakt, że próg deficytu strukturalnego (wymagany przez Traktat o funkcjonowaniu Unii Europejskiej) wchodzi w życie w 2020 r., może oznaczać, że przedstawiona regulacja konstytucyjna może posiadać w pewnym stopniu charakter postulatywny.

\section{Przepisy Unii Europejskiej dotyczące deficytu i długu publicznego}

Zgodnie z art. 126 Traktatu o funkcjonowaniu Unii Europejskiej ${ }^{15}$ Państwa Członkowskie zobowiązane są unikać nadmiernego deficytu budżetowego, a Komisja nadzoruje rozwój sytuacji budżetowej i wysokość długu publicznego w Państwach Członkowskich. Komisja bada stan budżetu Państwa Członkowskiego na podstawie dwóch kryteriów: a) czy stosunek pomiędzy planowanym lub rzeczywistym deficytem publicznym a produktem krajowym brutto przekracza 3\%, b) czy stosunek pomiędzy długiem publicznym a produktem krajowym brutto przekracza 60\%. Wspomniane wskaźniki unijne określone są w protokole w sprawie procedury dotyczącej nadmiernego deficytu, który jest załącznikiem do Traktatu o funkcjonowaniu Unii Europejskiej.

W razie przekroczenia tych wielkości organy Unii mogą wprowadzać odpowiednie działania i zalecenia zmierzające do ograniczenia deficytu, a w końcu - sankcje w stosunku do Państwa Członkowskiego, które nie ograniczyło deficytu (żądanie złożenia przez Państwo Członkowskie nieoprocentowanego depozytu, nałożenie na Państwo grzywny).

Przepisy UE nie mówią o deficycie budżetowym, lecz o deficycie publicznym, czyli deficycie całego sektora finansów publicznych. Ponadto stanowią one o długu publicznym, a nie tylko o długu Skarbu Państwa.

15 Dz.Urz. UE C 2008, Nr 115, s. 1. 
Art. 126 ust. 3 nawiązuje do przeznaczenia środków skierowanych na finansowanie deficytu publicznego. Wskazuje on na potrzebę uwzględnienia tego, czy deficyt publiczny przekracza publiczne wydatki inwestycyjne - sugeruje więc, że deficyt (jeżeli ma być stosowany) powinien być wykorzystywany na finansowanie inwestycji państwowych, nie na wydatki bieżące.

Sprawa deficytu publicznego i długu publicznego jest także istotna dla funkcjonowania Unii Walutowej (strefy euro). Decydującymi dla udziału w Unii Walutowej są tzw. kryteria konwergencji. Zgodnie z nimi tylko to państwo, które może wykazać niską stopę inflacji, niskie stopy procentowe, stabilny kurs walutowy i solidne finanse publiczne, ma prawo uczestnictwa w Unii Walutowej. Obecnie kryteria te określone są w art. 140 Traktatu o funkcjonowaniu Unii Europejskiej i w protokole załączonym do Traktatu.

Państwa członkowskie Unii Europejskiej, które nie spełniają warunków do przyjęcia waluty euro i nie stosują tej waluty, są - zgodnie z Traktatem - tzw. państwami członkowskimi objętymi derogacją (do tych państw należy m.in. Polska). Do państw tych nie stosuje się przepisów Traktatu dotyczących emisji euro, celów i zadań Europejskiego Systemu Banków Centralnych, środków przymusowych mających na celu zaradzenie nadmiernemu deficytowi budżetowemu (art. 139 ust. 2).

Państwa członkowskie objęte derogacją i ich krajowe banki centralne są wyłączone z praw i obowiązków w ramach Europejskiego Systemu Banków Centralnych (art. 139 Traktatu o funkcjonowaniu Unii Europejskiej). Stosują one więc własną walutę i prowadzą krajową politykę pieniężną poprzez działalność banku centralnego danego państwa (w Polsce - Narodowego Banku Polskiego) i jego instrumenty polityki monetarnej (np. stopy procentowe bonów pieniężnych NBP).

Sądzę, że własna polityka monetarna ułatwia prowadzenie polityki gospodarczej Państwa Członkowskiego. Umożliwia ona stosowanie instrumentów polityki monetarnej i fiskalnej znajdujące się bezpośrednio w gestii władz krajowych. Ponadto instrumenty własne danego państwa członkowskiego (monetarne, fiskalne, gospodarcze) pozwalają na osiąganie większego dynamizmu społeczno-gospodarczego tego państwa, przy- 
rostu jego aktywności, a tym samym - wzrostu aktywności Unii jako całości.

Istotne znaczenie prawne dla spraw długu i deficytu budżetowego ma - będący załącznikiem do Traktatu o funkcjonowaniu Unii Europejskiej protokół nr 12 w sprawie procedury dotyczącej nadmiernego deficytu. Wskazuje on i definiuje „wartości odniesienia”, o których stanowi art. 126 ust. 2 Traktatu o funkcjonowaniu Unii Europejskiej. Wartości te to (jak już wspomniano): 3\% dla stosunku planowanego lub rzeczywistego deficytu publicznego do produktu krajowego brutto wyrażonego w cenach rynkowych oraz $60 \%$ dla stosunku zadłużenia publicznego do produktu krajowego brutto wyrażonego w cenach rynkowych.

Protokół nr 12 precyzuje, że publiczny deficyt lub publiczny dług dotyczy całej władzy publicznej, czyli rządu centralnego, władz regionalnych lub lokalnych i funduszy ubezpieczeń społecznych. Deficyt - według Protokołu - oznacza pożyczki netto, zgodnie z definicją w Europejskim Systemie Zintegrowanej Rachunkowości Gospodarczej. Zadłużenie oznacza całkowitą sumę zadłużenia brutto w wartości nominalnej, występującą na koniec roku i skonsolidowaną dla wszystkich sektorów władzy publicznej.

Sporządzony w Brukseli dnia 2 marca 2012 r. Traktat o stabilności, koordynacji i zarządzaniu w Unii Gospodarczej i Walutowej, którego uczestnikami jest większość państw członkowskich Unii Europejskiej, i który został ratyfikowany przez wystarczającą liczbę państw (a więc wszedł w życie) jest prawem unijnym, odnoszącym się do spraw gospodarczych i budżetowych państw członkowskich, głównie do spraw zadłużenia i deficytu publicznego. Do jego stosowania zobowiązane są państwa strefy euro, ale także inne państwa, w tym objęte derogacją (nie należące do strefy euro), o ile oświadczą, że pragną być wcześniej związane wszystkimi lub niektórymi postanowieniami tego Traktatu.

Traktat o stabilności, koordynacji i zarządzaniu odwołuje się do przepisów Traktatu o funkcjonowaniu Unii Europejskiej (np. art. 121, 126, 136), do prawa Unii Europejskiej, w tym także Protokołu nr 12 w sprawie procedury dotyczącej nadmiernego deficytu, będącego załącznikiem do Traktatu o funkcjonowaniu Unii Europejskiej. 
Zgodnie z art. 1 Traktatu o stabilności z 2012 r. umawiające się strony, będące państwami członkowskimi Unii Europejskiej zgadzają się wzmocnić filar gospodarczy unii gospodarczej i walutowej poprzez przyjęcie szeregu reguł mających na celu wzmocnienie dyscypliny budżetowej paktem budżetowym, wzmocnienie koordynacji polityk gospodarczych oraz poprawę zarządzania strefą euro. Ma on pełne zastosowanie do państw, których walutą jest euro.

Tytuł III Traktatu o stabilności (art. 3-8) nosi nazwę Pakt budżetowy. Według art. 3 tego Traktatu saldo sektora instytucji rządowych i samorządowych umawiającej się strony musi być zrównoważone lub wykazywać nadwyżkę. Wymóg ten uważa się za spełniony, jeżeli roczne saldo strukturalne sektora instytucji rządowych i samorządowych odpowiada celowi średniookresowemu dla danego państwa, określonemu w pakcie stabilności i wzrostu, przy czym dolny pułap deficytu strukturalnego wynosi 0,5\% produktu krajowego brutto w cenach rynkowych. Każde państwo zapewnia szybkie dochodzenie do swojego celu średniookresowego. Ramy czasowe takiego zbliżenia zostaną przedstawione przez Komisję Europejską. Strony mogą tymczasowo odejść od swojego celu średniookresowego (dotyczącego deficytu) jedynie w „wyjątkowych okolicznościach”. Zasady przewidziane w Traktacie (dotyczące poziomu deficytu, zadłużenia, procedur budżetowych) powinny być wprowadzone do prawa krajowego, w miarę możliwości do przepisów rangi konstytucyjnej (art. 3 ust. 2 Traktatu).

Według Traktatu „roczne saldo strukturalne sektora instytucji rządowych i samorządowych” to saldo roczne (np. deficyt roczny), uwzględniające zmiany cykliczne, po skorygowaniu o działania jednorazowe i tymczasowe. Deficyt strukturalny sektora instytucji rządowych i samorządowych jest to więc deficyt trwały, wynikający ze stanu finansów publicznych w dłuższym czasie, „zakorzeniony” w systemie finansowym, skorygowany jednak o cykliczne, jednorazowe, doraźne operacje, które ten strukturalny deficyt okresowo zniekształcają. Wyjątkowe okoliczności, o których stanowi Traktat, to nadzwyczajne zdarzenie, na które państwo nie ma wpływu i które wywiera znaczący wpływ na sytuację finansową 
sektora instytucji rządowych i samorządowych, lub okresy znacznego pogorszenia koniunktury gospodarczej.

Traktat przewiduje obowiązki państw członkowskich dotyczące redukcji deficytu i wprowadzania reform strukturalnych, a także uprawnienia organów Unii (Komisji Europejskiej, Rady Unii Europejskiej, Trybunału Sprawiedliwości) w sprawach realizacji przepisów Traktatu. Przykładowo art. 6 postanawia, że w celu lepszej koordynacji planów w zakresie krajowych emisji długu, państwa członkowskie przedstawiają Radzie Unii Europejskiej i Komisji Europejskiej informacje ex ante na temat swoich planów emisji długu publicznego.

Ocena Traktatu o stabilności (,paktu fiskalnego”) dotyczącego zagadnień budżetowych, zwłaszcza dotyczących długu i deficytu, budzi poważne zastrzeżenia o charakterze konstytucyjnym i ustrojowym. Mamy tu przesunięcie decyzji budżetowych ze strony organów państw członkowskich (rządów, parlamentów) na poziom organów unijnych (Komisji, Rady, Eurogrupy). Przepisy Konstytucji o budżecie, uprawnieniach budżetowych parlamentu, władzy budżetowej państwa w stosunku do budżetu stają się fasadowe. Zdjęcie odpowiedzialności z rządu i parlamentu narodowego za sprawy budżetowe jest niewłaściwym posunięciem. Organy Unii nie mają bowiem dostatecznej siły egzekucyjnej, aby prowadzić sprawy budżetowe państwa i za nie odpowiadać. Jest wątpliwe, czy przepisy Traktatu są wykonalne. Za ich realizację musi wziąć odpowiedzialność państwo narodowe. Traktat zobowiązuje co prawda państwa członkowskie do przyjęcia przepisów Traktatu do prawa krajowego, ale wprowadzenie tych przepisów budżetowych pod naciskiem organizacji międzynarodowej może mieć charakter działań pozorowanych. Wydaje się, że sprawy budżetu i wydatków, głęboko wnikające w system społeczny danego kraju, w życie codzienne, w mentalność ludzi, w postawy mieszkańców wobec obowiązków, w wartości i tradycje - nie nadają się do regulacji międzynarodowych (w tym unijnych). Regulacje te mają raczej formalne znaczenie. Realne życie społeczne musi kształtować władza, mająca bezpośrednie (a nie tylko pośrednie) środki wykonawcze i instrumenty działania. 


\section{Wnioski}

Wydaje się, że regulacje konstytucyjne dotyczące długu publicznego i deficytu publicznego są istotne i potrzebne. Są normami skierowanymi do rządów i do parlamentów - organów władzy budżetowej, a pośrednio do całego społeczeństwa. Jednak mają one charakter prewencyjny, sygnalizacyjny. Nie mogą same przez się zatrzymać poziomu zadłużania się państwa. Ograniczanie długu wymaga zmian w licznych ustawach zwykłych, zarówno w sferze wydatków, jak i dochodów. Z kolei aby dokonać tych zmian i ograniczyć poziom zadłużenia publicznego, potrzebne są działania społeczne i gospodarcze mobilizujące obywateli do określonej, ukierunkowanej aktywności, realizacji wiarygodnego programu polityki gospodarczej państwa. Cele finansowe - dotyczące długu i deficytu - są bardzo trudne. Mogą być osiągnięte metodami niefinansowymi - odpowiednią polityką społeczną i gospodarczą, realizowaną przez władze cieszące się dużym autorytetem.

Sądzę, że regulacje UE dotyczące długu i deficytu okażą się mało skuteczne. Mogą one być wprowadzane w życie instrumentami prawa krajowego (m.in. przepisami ustaw). Ponadto bardzo wątpliwy i podważający autorytet państwa jest zespół przepisów unijnych ograniczających uprawnienia budżetowe państw członkowskich, w tym uprawnienia budżetowe rządów i parlamentów narodowych.

\section{Bibliografia:}

Banaszak B., Konstytucja Rzeczypospolitej Polskiej. Komentarz, C.H. Beck, Warszawa 2012.

Grodyński T., Zasady gospodarstwa budżetowego w Polsce na tle porównawczym, Polska Akademia Umiejętności, Kraków 1932.

Heintzen M., [w:] I. Münch, P. Kunig (red.), Das Finanzwesen, Grundgesetz Kommentar, C.H. Beck, wyd. 6, Monachium 2012.

Heller R.F., Haushaltsgrundsätze für Bund, Länder und Gemeinden, R. v. Decker, Heidelberg 2010.

Staśkiewicz W. (red.), Konstytucje państw Unii Europejskiej, Wydawnictwo Sejmowe, Warszawa 2011. 
Andrzej Borodo

Weinfeld I., Skarbowość polska, Z. 2 Budżet, kasowość, wydatki, dochody, długi, waluty, Wydawnictwo „Bibljoteka Prawnicza”, Warszawa 1933. 